
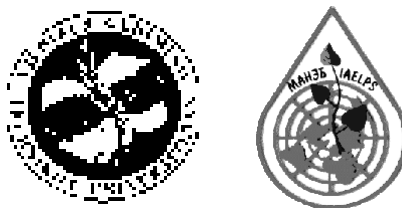

\title{
SOME ASPECTS OF MODELING BED PROCESSES IN TRAINED RIVERS
}

\author{
Saulius Vaikasas ${ }^{1}$, Mindaugas Stankevičius ${ }^{2}$ \\ ${ }^{1}$ Institute of Water Management, Lithuanian University of Agriculture \\ Parko 6, Vilainiai, LT-58102 Kèdainiai district, Lithuania \\ E-mail: s.vaikasas@delfi.lt \\ ${ }^{2}$ Dept of Hydraulic Engineering, Vilnius Gediminas Technical University \\ Sauletekio al. 11, LT-10223 Vilnius-40, Lithuania \\ E-mail: Mindaugas.Stankevicius@ap.vtu.lt
}

Received 15 Nov 2002; accepted 9 Jan 2003

\begin{abstract}
Physical modeling of sediment transport and morphology in rivers as well as wastewater dilution processes are closely related to the modeling of macro turbulent fluctuations. The physical modeling of hydraulic macro turbulent fluctuations is complicated and underestimated. The study of turbulent flow structure and verification as well as model calibration is required in this case.

Some methods of model verification by means of kinematics and turbulent coefficients scaling $\alpha_{\mathrm{Ka}}, \alpha_{x}$ and $\alpha_{K}$ are presented in the paper. Experience in hydraulic modeling of bed processes in the Neris and Nemunas rivers contributed to the viable results. As laboratory tests showed, after the scales of the Nemunas bed had been distorted 12 times, the turbulence of modeled flow increased causing 3 times more intensive wastewater dilution processes in a physical model of the Nemunas bed. When modeling the bed processes of the Neris in Vilnius in a hydraulic model with the scale distorted 6,7 times, it was determined that a more intensive turbulence caused a $25 \%$ thinner bed soil layer and nearly 3 times higher velocity of vertical turbulent flow. This was considered when calculating the results obtained in a model into natural ones and when choosing proper means for designing riverbed hydraulic structures.
\end{abstract}

Keywords: bed processes, turbulent flow, hydraulic modeling, scales.

\section{Introduction}

A complicated motion of suspended sediments and deposits contained in water flow is observed in riverbeds. This process has always been underestimated and difficult to calculate, although laboratory and natural studies have been creating new methods for sediment transport calculation and improving the existing ones [1]. To study the processes occurring in riverbeds and divert them to a necessary direction, the only method physical (hydraulic) modeling - needs to be applied in most cases. The method enables to recreate natural movement of sediments, to discover the unknown interrelation between the flow and sediment movement as well as to determine the characteristics of the interaction between sediments and turbulent flows.

However, the application of physical modeling methodology for the studies mentioned might cause certain disadvantages. The difficulties might occur during the tests that are to be made when seeking to guarantee limit conditions of the model and to obtain the identity of criteria describing the process [2-6]. This is due to the fact that rather complicated similarity conditions in the model must be created in order flow conditions in a hydraulic model would correspond to those in the riverprototype. This means that it is not enough to fulfill the requirements of geometric and hydrodynamic similarity criteria; the similarity of sediment motion itself in riverbeds is also needed. It is closely related to the ensured conditions of turbulent pulsation similarity of flows [7]. Currently, another urgent environment-protection problem related to the modeling of those conditions is faced, $i$ e the construction of wastewater outfall conduit and its location in the river. It is particularly of great importance when considering the construction of urban wastewater treatment facilities.

In our study hydraulic modeling was applied for investigating bed processes in the trained river Neris in Vilnius as well as for modeling wastewater treatment facilities dislocation and pollutant mixing processes in the Nemunas in Kaunas and Tilžè. The paper discusses the methodical aspects of such a modeling and suggests possible solutions of problems. 


\section{Conditions for possible turbulent flow similarity}

As mentioned above, sediment movement near the bottom as well as flow mixing process with different fluids (the so-called turbulent dispersion) are strongly affected by turbulent structure of flows (Fig 1). Flow turbulent structure influences the genesis of different sediment forms and their movement. A particularly important factor in hydraulics - hydraulic resistance - also depends on sediment forms and their motion.

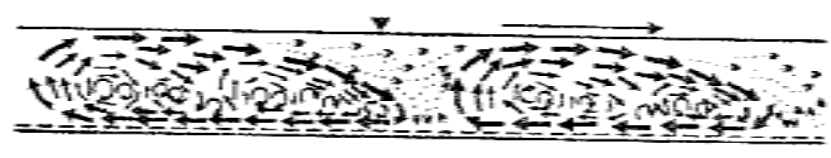

Fig 1. Two-dimensional turbulent flow

In the two-dimensional flow of Fig 1 the largest turbulent formations are essential. They lift ground particles up or drop them down mixing them with water flow and so affecting the distribution of flow velocities and sediments. This is the activity measured by most researchers, not the dynamics of particle motion that is particularly difficult to visualize. This might be the reason causing current studies of the influence of such turbulence flows on hydraulic measurements [8-10].

When modeling riverbed processes, the application of hydraulic flow similarity equations is of great importance:

$$
\begin{gathered}
\mathrm{Re}_{m} \geq \mathrm{Re}_{k r}, \\
\mathrm{Fr}_{m}=\mathrm{Fr}_{n},
\end{gathered}
$$

where: $\operatorname{Re}_{m}=\frac{V_{m} h_{m}}{v}-$ Reynold's criterion in a hydraulic model; $\mathrm{Fr}_{m}=\frac{V_{m}^{2}}{g h_{m}}-$ Frud's criterion in a hydraulic model; $\mathrm{Fr}_{n}$ - Frud's criterion in the river (prototype); $V_{m}$ - average velocity of a modeled flow; $h_{m}$ - average depth of a modeled flow; $v$ - kinematic viscosity coefficient of liquid (water); $g=9,81 \mathrm{~m} / \mathrm{s}^{2}$ - gravity acceleration; $\operatorname{Re}_{k r}=3150$ - critical value of Reynold's number expressing the flow in auto-modeled zone of square flow resistance.

When considering these criteria, modeled flow velocities and depths and their distribution should be similar to those of the prototype. Water discharge distribution in river branches would also be similar. However, in practice, in order to apply equation (1), the scale of flow depths $\alpha_{h}=h_{n} / h_{m}$ should be chosen different from $\alpha_{l}=l_{n} / l_{m}$. During the riverbed modeling process this means that the shape of the riverbed and its bottom relief are distorted. Moreover, in order to ensure the identity of Frud's criteria of flows expressed in equation (2) in such a model of distorted scales the hydraulic resistance of flow should be increased in the model and stron- ger hydraulic roughness should be created. In most models stronger hydraulic resistance is created by model calibration, $\mathrm{i}$ e in an empiric way. However, such a method is applicable only under non-modeled sediment conditions, as sediments move according to the mentioned pulsations induced by macro turbulent fluctuations. It is impossible to change sediment motion by increasing hydraulic roughness. Therefore, in order to create similar movement of transported sediments, microforms and mezoforms in a modeled riverbed, the following equations related to the similarity theory are to be considered:

$$
\begin{aligned}
& H / h_{r}=i d e m, \\
& h_{r} / l_{r}=i d e m, \\
& U / C_{r}=i d e m,
\end{aligned}
$$

where $H, h_{r}, l_{r}, C_{r}$ and $U-$ flow depths, depth of bottom sediment layers, their length, movement velocity and average flow velocities, respectively.

The above equations determine the geometrical scales of the model and their distortion degree, which implies that prototype flows should be recreated in the model considering the pulsation period of their largest vortices (i e the scale of turbulent pulsation). Under such conditions the scale of average and momentary velocities would remain the same and correspond to the requirements of equation (2):

$$
\alpha_{v}=\alpha_{v}=\sqrt{\alpha_{h}} .
$$

As the modeling practice shows, large-scale pulsations are determined by the flow depth and width, $i$ e in order to recreate the pulsations, geometrical scales of the model should not be distorted. To determine the movement regularities of suspended sediments an appropriate size of sediment particles is needed. It is calculated with the help of Lochtin's (or Schield's) similarity criterion:

$$
\Psi_{L}=\frac{H i}{\rho_{*} d}=i d e m
$$

where: $i$ - hydraulic gradient (energy line gradient); $d-$ average diameter of transported particles; $\rho_{*}=\frac{\rho_{s}-\rho}{\rho}-$ relative density of sediments in flow; $\rho_{s}$ - sediment density; $\rho$ - water density.

To coordinate all these requirements in practice is not an easy matter requiring models with a large nondistorted geometrical scale, coarse sediments in modeled rivers and a strong flow. Therefore, when modeling riverbed processes in the Neris in Vilnius (Fig 2), the discrepancies of water flow structure of the selected model were evaluated according to equation (7) $[2,4,5]$. In this case the kinematic coefficients of turbulent flows by A.S. Altunin were used [3]. 
The coefficient of turbulent flow of the border layer $(x)$ in the model was determined for this purpose [6]:

$$
x=\delta /(h-\delta)=\left(U_{\max } / U_{B}-1\right),
$$

where: $\mathrm{d}$ - depth of the bottom layer; $h$ - flow depth in a vertical; $U_{\max }, U_{B}$ - the biggest and average flow velocities in a vertical.

The coefficient $k$, determining the vertical sediment movement velocity of turbulent vortices in practice and in the model, was expressed from the following equation:

$$
k=U_{*} /\left(U_{\max }-U_{B}\right),
$$

where $U_{*}=\sqrt{g h i}$ - bed-shear velocity of the flow; $i-$ average flow gradient in the studied section.

The values $x$ and $k$ were calculated considering the measurement data of natural and modeled hydraulic parameters in the cross-section at picket 163,9 (Figs 2, 3).

The calculation results were as follows: $x_{m}=0,081$, $k_{m}=2,32$ (modeled) and $x_{n}=0,124, k_{n}=0,630$ (natural). The scale of kinematic coefficients was obtained as follows:

$$
\begin{gathered}
\alpha_{x}=x_{n} / x_{m}=1,54 ; \\
\alpha_{k}=k_{n} / k_{m}=0,295 .
\end{gathered}
$$

On the basis of these characteristics, the actual vertical scale of the model was verified:

$$
\begin{aligned}
& \alpha_{h}=\alpha_{\rho} \alpha_{d} / \alpha_{X}^{2} \alpha_{K}^{2}=1 \cdot 3,2 / 1,54^{2} \cdot 0,295^{2}= \\
& =15,5 \approx 15 .
\end{aligned}
$$

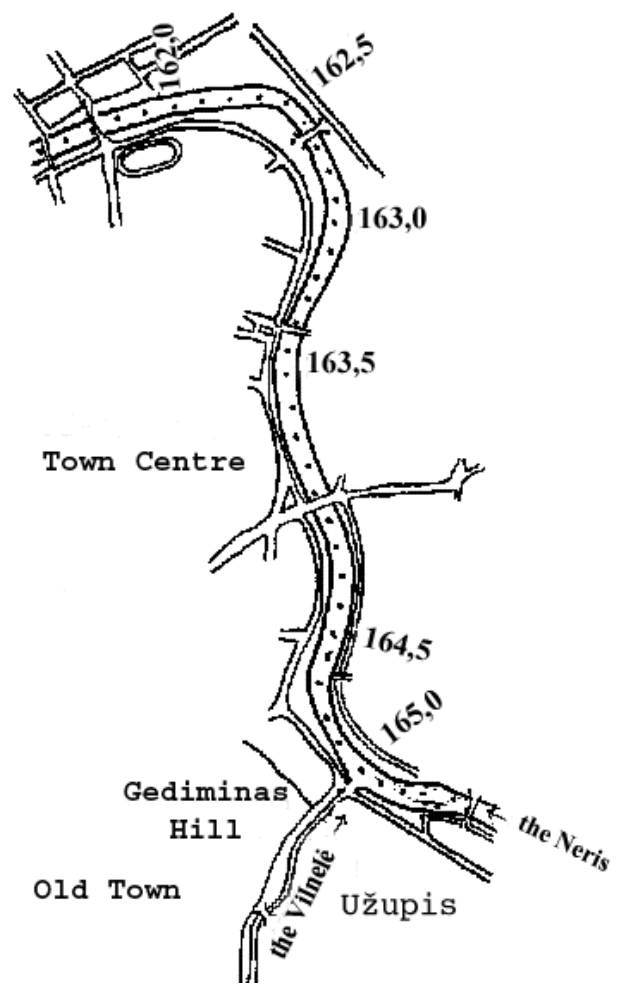

Fig 2. Scheme of the riverbed in a modeled section of the Neris (pickets - every $100 \mathrm{~m}$ from the river mouth)

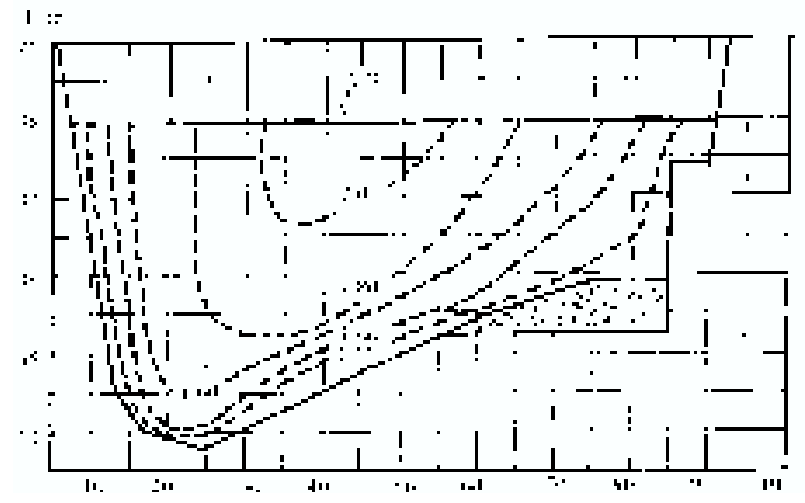

Fig 3. Cross-section of flow distribution at picket 163,9 with bed-forming discharge $Q_{\max }=600 \mathrm{~m}^{3} / \mathrm{s}$

The actual scale of comparative and actual discharges of bottom sediments $\left(\alpha_{q T}\right.$ and $\left.\alpha_{Q T}\right)$ was obtained as follows:

$$
\begin{gathered}
\alpha_{q T}=\alpha_{v}^{3} \alpha_{x}^{3} \alpha_{k}^{3}=5,95 ; \\
\alpha_{Q T}=\alpha_{q T} \alpha_{l}=595 .
\end{gathered}
$$

The auto-modeling of water flow movement regime in the model was verified considering Reynold's criterion:

$$
\operatorname{Re}_{m}=V_{m} h_{m} / v=370000>\operatorname{Re}_{k v},
$$

where $\mathrm{Re}_{k v}$ - boundary value of $\mathrm{Re}$ criterion for the zone of square resistance; $\mathrm{Re}_{k v}=1 \cdot 10^{5} ; \mathrm{Re}_{m}-$ Reynold's criterion in the model; $V_{m}$ - average flow velocity of the model in a vertical; $h_{m}$ - measured depth of a vertical in the model.

Moreover, water flow roughness of the model was verified considering Frud's number:

$$
\mathrm{Fr}_{m}=V_{m}^{2} / g h_{m}=0,03<1 \text {. }
$$

As the specified dependences (14-16) show, proper scales were selected for the model and necessary water flow regime was recreated. Moreover, additional comparison of sand-formed shoals in the model with natural shoals at the Green Bridge and the Vilnele mouth was made (Fig 3). The results appeared to be very similar too.

The study has determined no obvious changes in the bed bottom height in the Neris during the modeling process of fluctuating sediment discharge. Thus, there is a certain degree of auto-modeling of the process under investigation from the point of view of modeled sediment discharge. Therefore, satisfactory results might have been expected, even if the natural or modeled sediment discharge was not calculated precisely enough.

There is some more interesting field measuring results of the riverbed fluctuations. In 1978, during the training of the right bank of the Neris nearby the Department Store (before the embankment was erected here), a $2 \mathrm{~m}$ deep shoal was made here. In 1979 the topographic photos of this section showed that after spring floods had fin- 
ished, the bottom was covered with sediment again and rose up by $0,9-1,2 \mathrm{~m}$. This implies that shoals and shallow places could be avoided here only after regulating the hydraulic regime of the river bed.

\section{Modeling results of the riverbed regulation means}

The influence of the following most frequently applied riverbed regulation means was studied: 1) spillweirs; 2) embankments regulating the width of the riverbed; 3) river-training spurs [4, 5] (Fig 4).

The regulation of the Neris bed, when a cascade of low spillweirs raises water, was most supported by the local government. To study the hydraulic effect of this means, a spillweir was modeled in the section between the Green Bridge and Pedagogical University at picket 164,5 . The top of the spillweir was $1,4 \mathrm{~m}$ below the berms of the embankment. Unfortunately, sediments were continuously covering the upper bay. The sediments accumulated here by creating sandy shoals that might have even reached the very top of the spillweir. Under the conditions of a minimal discharge these shoals might have come to the surface.

Thus, such a water level regulation means was not acceptable in this case. This means might be applied only if a spillweir contained special shields that would be opened during spring floods or high water heads and closed again in summer when the discharge is minimal. A spillweir with such a regulation would not impede the formation process of the riverbed. For instance, such type of the device is erected in the branch of the Meuse in the Netherlands [11] (Fig 5). Inflatable spurs or movable shields between bridge piers would also be suitable.

Other ways of river regulation result in the riverbed constriction. In the model the riverbed was constricted with the help of embankments and river-training spurs. As it was determined, sand sediments of shallow places were not affected enough when the riverbed is constricted only to the width of $70 \mathrm{~m}$. In this case a maximum height of the sediment layer is reduced only to $0,10-0,15 \mathrm{~m}$. When the river bed width is constricted to $65 \mathrm{~m}$, sand shoals are
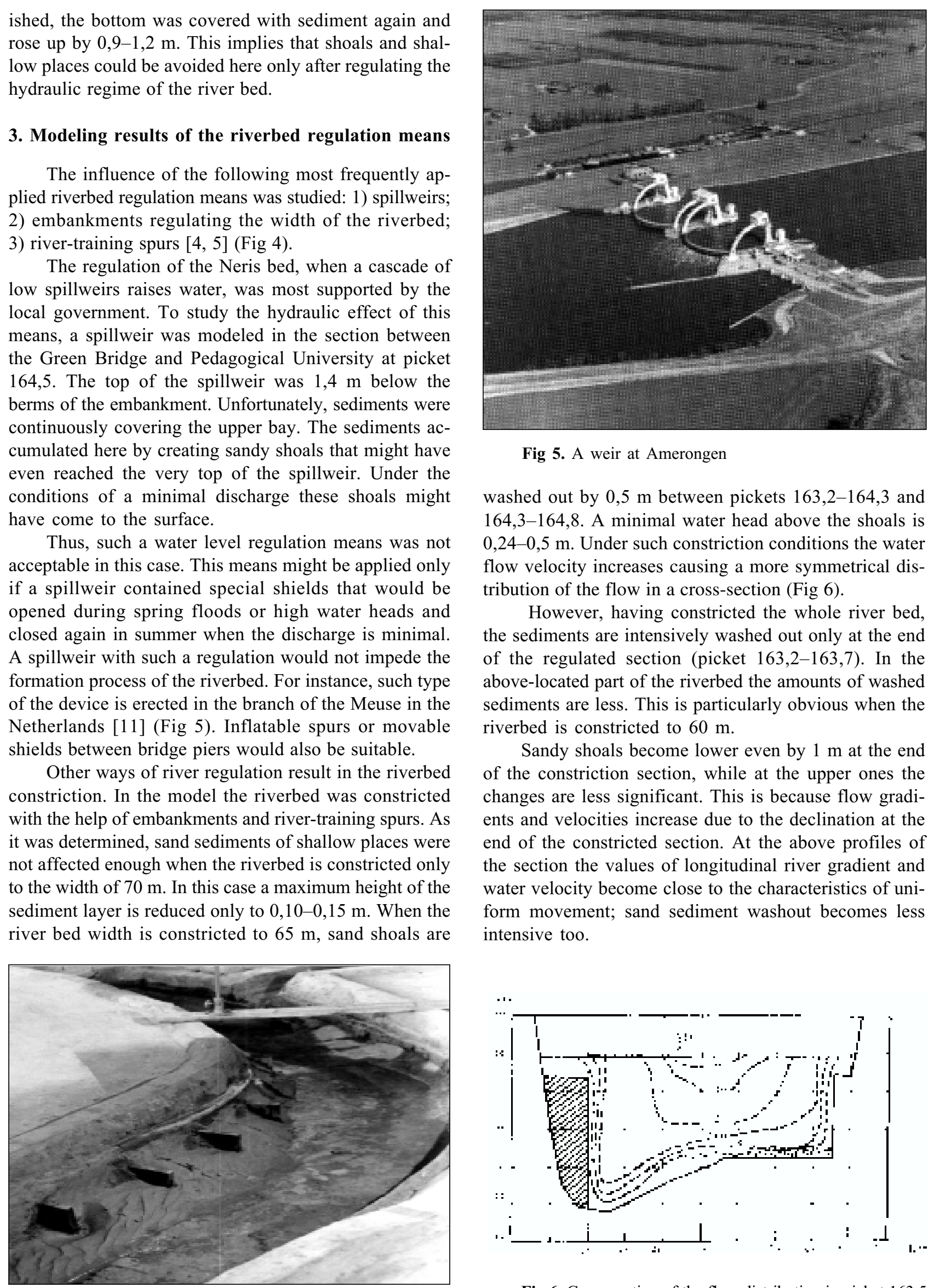

Fig 5. A weir at Amerongen

washed out by $0,5 \mathrm{~m}$ between pickets $163,2-164,3$ and 164,3-164,8. A minimal water head above the shoals is $0,24-0,5 \mathrm{~m}$. Under such constriction conditions the water flow velocity increases causing a more symmetrical distribution of the flow in a cross-section (Fig 6).

However, having constricted the whole river bed, the sediments are intensively washed out only at the end of the regulated section (picket 163,2-163,7). In the above-located part of the riverbed the amounts of washed sediments are less. This is particularly obvious when the riverbed is constricted to $60 \mathrm{~m}$.

Sandy shoals become lower even by $1 \mathrm{~m}$ at the end of the constriction section, while at the upper ones the changes are less significant. This is because flow gradients and velocities increase due to the declination at the end of the constricted section. At the above profiles of the section the values of longitudinal river gradient and water velocity become close to the characteristics of uniform movement; sand sediment washout becomes less intensive too.

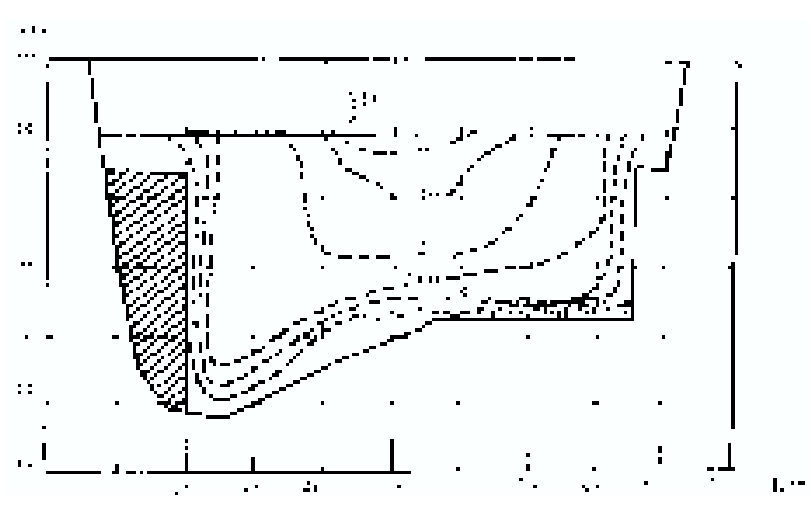

Fig 4. River bed regulation with river-training spurs (fragment of the Neris hydraulic model)

Fig 6. Cross-section of the flow distribution in picket 163,5 when the river bed width is constricted to $65 \mathrm{~m}\left(\mathrm{Q}_{\max }=\right.$ $600 \mathrm{~m}^{3} / \mathrm{s}$ ) 
In the river bed regulated by river-training spurs the washing of sandy shoals was more intensive than in the river bed constricted by embankments. For example, when the river bed width between river-training spurs is $65 \mathrm{~m}$ at pickets $163,4-163,7$, shoals become lower by more than $0,52 \mathrm{~m}$. Having constricted the river bed with the help of river-training spurs to $60 \mathrm{~m}$, shoals at pickets $164,1-164,3$ and 164,6 become even by $1 \mathrm{~m}$ lower. Such an effective action of river-training spurs is due to the common deviation of the dynamic axis of the Neris flow towards the bend of the river bank. Moreover, rivertraining spurs were used for the constriction of rather short sections $(100-300 \mathrm{~m})$ in the zones of shoal formation; therefore, non-constricted sections situated below did not induce the upstream head of the section above. Thus, river-training spurs were effective enough, except for their architectural structure.

Considering the modeling-based river bed regulation experience, one of the most effective ways of river bed regulation was created, when the river bed was constricted by embankments only at its turning points, i e the spots where shoals are formed nearby the bend of the river bank. In this case the shoals are washed out to the same extent as in the case of river-training spurs. In straight sections the riverbed becomes wide again. Here the water head is not very high and the above-situated sections are not flooded. Thus, it is possible to regulate riverbed sections of any length. According to the data selected by the Institute of Industrial Constructions Design, such river regulation methods appeared to be the most economical and viable. On the basis of the study data, empirical dependences between the river bed constriction at its turning points, the bend radius $\mathrm{R}$ and river gradient I were determined (Fig 7).

Considering these dependences, optimal width of the riverbed at each turning point of the regulated section of the Neris was calculated. This riverbed regulation approach was applied for the Neris in Vilnius. Additional natural observations of the trained riverbed carried out in this vicinity in 1980-2002 proved the correctness of the results obtained by the modeling method (Fig 8).

\section{Hydraulic modeling of pollution dispersion and mixing in the riverbed}

The selection of an optimal place for pre-treated wastewater discharge into the Nemunas in the towns of Russia Sovietsk (Tilžè) and Neman (Ragainè) is a top problem of environmental protection. During the studies non-treated wastewater from the towns mentioned was discharged into the Nemunas at a distance of 55 and $72 \mathrm{~km}$. Total wastewater discharge was $3 \mathrm{~m}^{3} / \mathrm{s}$. The largest volume of wastewater was discharged from largescale chemical industry enterprises - the Cellulose Plant and Paper Mill in Sovietsk and Neman. This industrial wastewater contained high pollution concentrations and needed treatment. Therefore, during the implementation

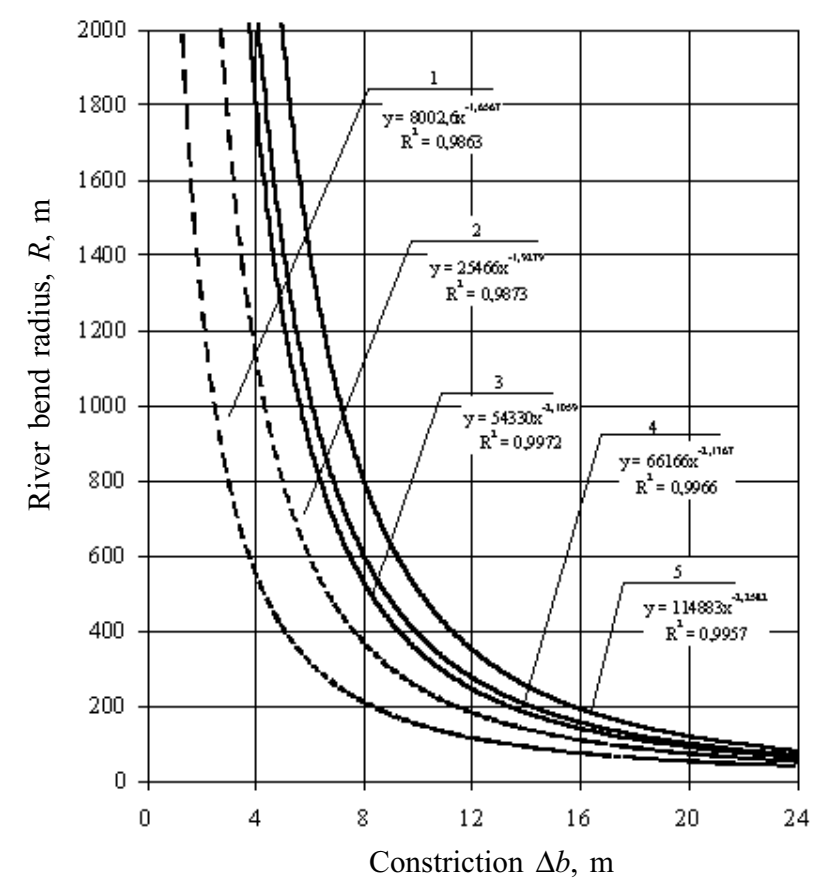

Fig 7. Dependence of the Neris bed constriction $\Delta b=$ $f\left(R_{1} i\right)$ influenced by river training points and gradients

$1-i=0,00021 ; 2-i=0,00028 ; 3-i=0,00031 ; 4-$ $i=0,00037 ; 5-i=0,00058$; optimal river bed width of straight sections $B(m) 79,75,70$ and 67 , when $i$ is 0,00058 , $0,00037,0,00031,0,00028$ and 0,00021 , respectively.

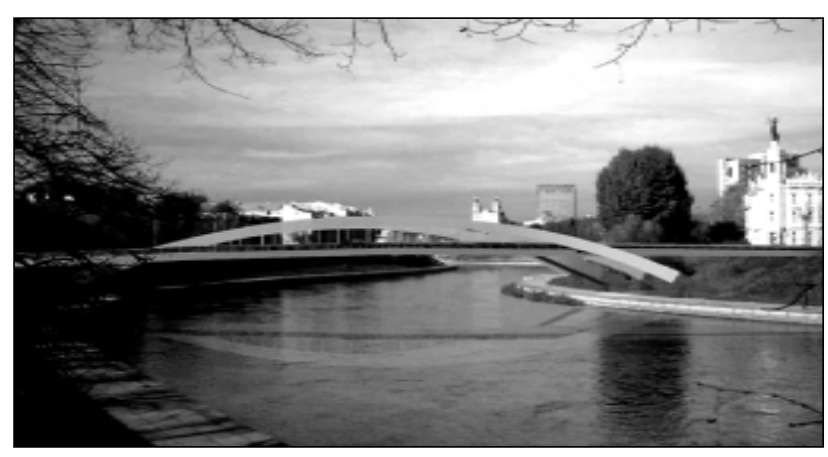

Fig 8. The trained river Neris in Vilnius

of the resolution made by the Cabinet Council of exUSSR "About the protection of the Baltic Sea watershed from pollution", new wastewater treatment facilities were planned to be constructed at the places of wastewater outflow. However, when designing the facilities certain problems occurred: where the wastewater outflow spots should be arranged? Is it necessary to build two separate wastewater treatment facilities? Answers to these and other questions might be found only after modeling the process of polluted water dispersion (diffusion) in the riverbed. Therefore, on the basis of a cooperation contract with the organization "Inzspecstroj" (Kaliningrad), the staff of the Lithuanian Institute of 
Water Management has studied the intensity of wastewater mixing process in different wastewater outflow spots in the model of the Nemunas delta, and an optimal construction for outlets has been determined.

In dry summer and winter periods the pollution experienced by the river is the most intensive. Biologically treated water with the concentration of organic matter $S \approx 15 \mathrm{mg} \mathrm{O} / 1$ (according to $\mathrm{BOD}_{5}$ ) was discharged into the river water. The maximum discharge of wastewater was rather small $\left(q_{0}=3 \mathrm{~m}^{3} / \mathrm{s}\right)$ compared to the minimal one of $95 \%$ probability of dry summer period in the Nemunas at Sovietsk $\left(Q_{0}=160 \mathrm{~m}^{3} / \mathrm{s}\right)$. Therefore, to have the most effective reduction of wastewater concentration, the fresh river water and wastewater should be fully mixed. After the fresh water and wastewater is mixed, the amount of organic load in one liter of the Nemunas water would increase insignificantly $-15 \cdot 3 / 160=0,28 \mathrm{mg} / \mathrm{l}$, i e only by $19 \%$, because, according to H. A. Velner, the concentration of organic load in non-polluted water of the Nemunas $S_{50 \%}$ reaches about $1,5 \mathrm{mg} / 1$ [4]. Therefore, in our study an emphasis was put on the length of water-mixing path in different spots of wastewater discharge, when wastewater discharge is concentrated.

Hydraulic modeling was chosen for the study for the following reasons:

1. For the proper selection of wastewater discharge spots, water flow dynamics in the riverbed needs to be studied. Appropriate natural study would be too long and expensive, and the testing of outlet constructions would be impossible in this case. On the other hand, a rather large section of the studied riverbed has already been modeled during the arrangement of the Nemunas delta model. Only several additional arrangements needed to be done and a larger fragment model of the studied riverbed section with small distortion of geometrical scales needed to be constructed.

2. Current results of the application of water dilution calculation methods based on empirical equations are diverse and unreliable, since it is not an easy task to evaluate the coefficients of turbulent diffusion. Turbulent diffusion modeling related to the turbulent fluctuations and structure of flows was similar to the previously analysed questions of fine sediment transport.

For the hydraulic study of the Nemunas riverbed flows, a model of the Nemunas delta was used. The scales of the delta model were as follows: target scale $\alpha_{l}=600$; vertical scale $\alpha_{h}=50$; discharge scale $\alpha_{Q}=$ 100000 ; velocity scale $\alpha_{v}=3,33$. The selection of model scales, model calibration and related questions were discussed in previous papers and transactions [2, 6, 10]. As modeling practice and comparison of modeled and natural results have shown, hydraulic modeling is particularly suitable for the recreation and investigation of stable flow and water head regime in the Nemunas. However, in this case the turbulent mixing of wastewater and fresh water needed a thorough study. Therefore, the possibilities for the modeling of this process and recalculation of modeled results into natural ones needed to be analysed.

As the analysis of pollutant mixing in rivers shows, the above-mentioned turbulent diffusion is decisive in this process. It might be expressed by a semi-empirical equation of turbulent diffusion: $\mathrm{p}-1$

$$
\frac{\partial S}{\partial t}+V \frac{\partial S}{\partial x}-k_{x} \frac{\partial^{2} S}{\partial x^{2}}-k_{y} \frac{\partial^{2} S}{\partial y^{2}}-k_{z} \frac{\partial^{2} S}{\partial z^{2}}=0
$$

where $S$ - pollution concentration; $V$ - average flow velocity; $k_{x}, k_{y}, k_{z}$ - average coefficients of turbulent diffusion of the profile. These coefficients express the intensity of turbulent diffusion with a certain direction. The relationship between the coefficients and hydraulic characteristics of measured flows is rather complicated and under a thorough investigation. The coefficients are closely related to the velocity pulsation and vortices of a different size that are generated by the bottom and slopes of the riverbed. According to A. V. Karausev, the average coefficients of turbulent diffusion in a studied river section might be expressed as follows:

$$
k_{v i d}=\frac{\gamma \cdot H_{v i d} V_{v i d}}{M C_{f}},
$$

where $k_{v i d}$ - coefficient evaluating the effect of turbulent diffusion on the mixing process of pollutants; $\gamma$ - volumetric weight of water; $H_{v i d}$ - average river depth; $V_{v i d}-$ average velocity; $C_{f}$ - Chezy coefficient; $M$ - function of Chezy coefficient when $10 \leq C \leq 60, M=0,70 \div 6$.

The water flows in the Nemunas bed and in the model are turbulent. Thus, water motion in the flows might be expressed by the following Reynold's equation:

$$
\begin{aligned}
& \frac{\partial V}{\partial t}+V \frac{\partial V}{\partial x}=g i+\frac{\partial}{\partial x}\left(\overline{V_{x}^{\prime} V_{x}^{\prime}}\right)+\frac{\partial}{\partial y}\left(\overline{V_{y}^{\prime} V_{x}^{\prime}}\right)+ \\
& +\frac{\partial}{\partial z}\left(\overline{V_{z}^{\prime} V_{x}^{\prime}}\right)
\end{aligned}
$$

where $g$ - gravity acceleration; $i$ - flow declination; $\overline{V_{x}^{\prime} V_{x}^{\prime}}, \overline{V_{y}^{\prime} V_{x}^{\prime}}, \overline{V_{z}^{\prime} V_{x}^{\prime}}$ - average products of pulsation velocities expressing tangential stress of turbulent friction.

Having inserted average values from the point of view of time and space with no dimensions into equation (19), certain changes are made resulting in the following equation:

$$
\begin{aligned}
& \frac{\partial \tilde{V}}{\partial \tilde{t}}+\mathrm{V} \frac{\partial \tilde{V}}{\partial \tilde{x}}=g \frac{H_{v i d}}{\mathrm{~V}_{v i d}^{2}} I+\left(\frac{\omega_{v i d}^{2}}{V_{v i d}}\right) \\
& \cdot\left[\frac{\partial}{\partial \tilde{x}}\left(\overline{\tilde{V^{\prime} x \tilde{V^{\prime} x}}}\right)+\frac{\partial}{\partial \tilde{y}}\left(\overline{\tilde{V^{\prime} y \tilde{V^{\prime} x}}}\right)+\frac{\partial}{\partial \tilde{z}}\left(\overline{\tilde{V^{\prime} z V^{\prime} x}}\right)\right]
\end{aligned}
$$

where $\tilde{V} x \tilde{V x}$ - average products of average pulsation velocities from the point of view of space; $\omega_{\text {vid }}$ - average 
velocity pulsation from the point of view of time and a vertical.

The term $\omega^{2}{ }_{v i d} / V_{v i d}$ in equation (20), i e the relation between an average vertical squared pulsation velocity and an average velocity specifies the turbulent pulsation of the flow and is called Karman's number Ka $\left(\mathrm{Ka}=\omega_{\text {vid }} / V_{\text {vid }}\right) . \mathrm{Ka}$ is directly proportional to the coefficient of turbulent diffusion $K_{v i d}$. This interrelation is expressed by the following equation:

$$
\mathrm{Ka}^{2}=a^{2} \frac{g k_{v i d}}{\gamma \cdot H_{v i d} V_{v i d}},
$$

where $a$-proportionality coefficient obtained when expressing the fluxions of velocity pulsations by the fluxions of average velocity. On the basis of natural study, $a \sim 1$ in the Nemunas. After special experiments were carried out in the model, it was obtained that $a_{m}=1,26$. With the expression of $k_{v i d}$, the following equation is obtained:

$$
\mathrm{Ka}=\sqrt{\frac{g}{M C_{f}}} .
$$

Thus, the value Ka might be a criterion of natural and modeled flow turbulence. The scale of our model was distorted (distortion degree $k=\alpha_{l} / \alpha_{h}=12$ ). Apart from other factors, such a distortion was also determined by the necessity of auto-modeling according to Reynold's criterion, i e $\operatorname{Re}_{m} \geq \mathrm{Re}_{k r}$. Thus, our model was not identical according to criterion $\mathrm{Ka}$, i e $\mathrm{Ka}_{n} \neq \mathrm{Ka}_{m}$. This factor affected the turbulence of the model and increased the coefficient of turbulent diffusion. Therefore, the scale of turbulence $\alpha_{\mathrm{Ka}}$ was determined:

$$
\alpha_{\mathrm{Ka}}=\sqrt{\frac{\alpha_{g}}{\alpha_{m} \alpha_{c}}}=\frac{1}{0,7 \alpha_{c}^{2}+6 \alpha_{c}},
$$

where $\alpha_{g}=1-$ scale of acceleration of gravity; $\alpha_{m}-$ scale of Businesk coefficient, $\alpha_{c}-$ scale of Chezy coefficient. The scale of Chezy coefficient is

$$
\alpha_{c}=\frac{C_{n}}{C_{m}}=\frac{\alpha_{h}^{1 / 6}}{\alpha_{n}} \cong 1,5,
$$

thus, in our model it was obtained as follows:

$$
\alpha_{\mathrm{Ka}}=\frac{1}{\sqrt{11,25}}=\frac{1}{3,35},
$$

where $\alpha_{h}-$ vertical scale equal to 50 in the model; $\alpha_{n}-$ roughness scale equal to 1,5 in the model.

When turbulent pulsation is 3,35 times higher in the model, the mixing process is also expected to be more intensive here. This condition was checked in a $20 \mathrm{~m}$ long hydraulic flume with fluctuating gradient containing a modeled straight section of the Nemunas bed with distorted and non-distorted scales.

Wastewater was simulated by intensively colored water and white salt solution. Color and salt concentrations were measured by a photo colorimetric method and determined by chemical analysis. The volume of samples was $100-150 \mathrm{~cm}^{3}$. Under natural conditions this would make up 10-15 $\mathrm{m}^{3}$. Therefore, the measured concentration is average for a rather large amount of water. Polluted water $(q=0,01-0,03 \mathrm{l} / \mathrm{s})$ was discharged from a special tank where natural head was decreasing insignificantly. Hydraulic flow characteristics were determined with the help of common laboratory measurement devices: micro-gauges, micro-mills and Pitt-type pipes. As the laboratory measurements have shown, the distortion of a model scale for 12 times results in a better mixing of pollutants; pollution concentration is reduced 3,3 times in the whole studied section compared to the model with non-distorted scales. Obviously, this corresponds to the turbulence scale $\alpha_{\mathrm{Ka}}$ obtained according to the dependence (23). Thus, in order to recalculate modeled concentration into natural one, it should be multiplied by the scale $\alpha_{\mathrm{Ka}}=3,3$. The length of the mixing path is calculated having multiplied a length measured in the model by the scale of the length $\alpha_{l}=60$ and $\alpha_{\mathrm{Ka}}$.

\section{Conclusions}

1.Distortion of geometrical scales of the hydraulic model enhances the macro-turbulence of modeled flow and the intensity of riverbed processes. This is to be considered when recalculating sediment discharges and movement velocities obtained by a modeling method according to the kinematic scales $\alpha_{x}$ and $\alpha_{K}$.

2. When determining the similarity of kinematic structure of natural and modeled flows by the method of hydraulic modeling with distorted geometrical scales, studies on the Neris bed processes in Vilnius were carried out. As the study results have shown, the best regulation method of the Neris water head is the constriction of the riverbed to $60-65 \mathrm{~m}$ at its turning points as well as the broadening of the riverbed to $70-75 \mathrm{~m}$ in its straight sections. Such a regulation methodology ensures the strongest effect of riverbed regulation means.

3. During the modeling of pollution dispersion and mixing processes the turbulence scale $\alpha_{\mathrm{Ka}}$ is to be evaluated.

4. Hydraulic study of pollution dispersion and mixing process in the Nemunas bed was carried out on the basis of flow turbulence recalculation methodology discussed in the paper. It is determined that the distortion of geometrical scales of the model 12 times enhances the pollutant mixing capacity 3,3 times in the model, i e the mixing capacity corresponds to the scale of flow turbulence $\alpha_{\mathrm{Ka}}$.

\section{References}

1. Van Rijn, L. C. Principles of sediment transport in rivers, estuaries and coastal seas. AQUA Publications, Delf, The Netherlands, 1993. 690 p.

2. Okunevičius, S.; Rimkus, A.; Vaikasas, S.; Rimkus, G. Modelling of the River Bed Regulation Process and 
Hydrotechnical Constructions (Hidroitvaru ir vaginių procesu modeliavimas). LMI mokslo darbai, Vol 22, Vilnius, 1993, p 16-46 (in Lithuanian).

3. Sharp, J. J. Hydraulic modelling. London-Boston-SydneyWellington-Durban-Toranto, 1984. 279 p.

4. Rainys, A.; Vaikasas, S. Changes of Bed Processes after the Neris River Training in Vilnius (Neries vaginiu deformacijų dinamika ir jos pokyčiai, sureguliavus vagą). LTSR MA ZPI mokslo darbai. Vilnius, 1988, p 20-40 (in Lithuanian).

5. Vaikasas, S.; Rainys, A. Impact of River Training on the Alteration of the Neris Riverbed in Vilnius (Труды 5-ого всесоюзного гидрологического съезда). Leningrad, Vol 10(1), 1988, p 425-431 (in Russian).

6. Vaikasas, S. Development and Application of Hydraulic Modeling in Polder Investigation. Doctor dissertation theses. Vilainiai, Kèdainiai, 1993, 8 p (in Lithuanian).

7. Klaven, A. B. Structure of Turbulent Flows and Methodical Background of Hydraulic Modelling (Структура турбулентности речных потоков и методические основы и моделирование на гидравлических деформируемых моделях). St Peterburg, 1996. 62 p (in Russian).

8. Rimkus, A.; Vaikasas, S. The length of laboratory channels necessary for the stabilization of suspended flow. Transaction of LUA and LIWM, No 18(40), 2002, p 59-64.

9. Vaikasas, S. Results of Mathematical Modelling on Dynamics of Flood Sediments within the Flooded Nemunas Delta. LŽUUU ir LVŨI mokslo darbai, No 14(36), 2001, p 61-74 (in Lithuanian).

10. Vaikasas, S. Flood dynamics and sedimentation-diffusion processes in riverbeds and inundated river valleys. Abstract of doctor habilitus dissertation. Vilainiai, Kèdainiai, 2001. $61 \mathrm{p}$ (in Lithuanian).

11. Ministry of Transport, Public Works and Water Management, RIZA Institute for Inland Water Management and Waste Water Treatment. Twice a River (Rhine and Meuse in the Netherlands). RIZA report No 99.003, 1999. 127 p.

\section{VAGINIŲ PROCESŲ REGULIUOJAMOSE UPĖSE MODELIAVIMAS}

\section{S. Vaikasas, M. Stankevičius}

\section{S a n trauka}

Vaginių procesų reguliuojamose upès dalyse bei dugniniu nešmenų judejjimo modeliavimas labai siejasi su prototipo turbulentinių fliuktuacijų modeliavimu. Tai būdinga ir šiuo būdu tiriant kanalizuoto vandens išleidimo, sklaidos bei susimaišymo procesus reguliuojamose upèse. Turbulentinių tėkmių fliuktuacijų modeliavimas sudètingas ir iki šiol mažai tyrinètas.

Straipsnyje, atsižvelgiant i turbulentinių fliuktuacijų bei kinematiškumo mastelius $\alpha_{\mathrm{Ka}} ; \alpha_{x}$ ir $\alpha_{K}$, pateikiama keletas atliekant hidraulini modeliavimą gautu tèkmès charakteristikų perskaičiavimo būdų. Akcentuojama, kad norint perskaičiuoti taip gautus rezultatus į natūrinius, būtina daugiau dèmesio skirti turbulentinès tèkmès struktūrai ir taikomų fizinių modelių veri- fikavimui bei kalibravimui. Aprašyti ir konkretūs šių perskaičiavimų pritaikymo pavyzdžiai tiriant Neries ir Nemuno reguliuojamų ruožų kinematiką. Laboratoriniai matavimai parodè, kad 12 kartų iškreipus Nemuno vagos mastelius, padidèja modeliuojamos tèkmès turbulentiškumas, kartu 3 kartus suintensyvejja išleidžiamų i upę teršalų sklaidos bei susimaišymo procesai Nemuno vagos fiziniame modelyje. Modeliuojant vaginius procesus Neryje Vilniaus mieste, 6,7 karto iškreipto mastelio hidrauliniame upès modelyje gauta, kad dèl padidejusio turbulentiškumo $25 \%$ sumažèja lyginamasis priedugnio sluoksnio storis ir beveik 3 kartus padideja turbulentinis vertikalusis sūkurių kilimo greitis. I tai atsižvelgta perskaičiuojant modelyje gautus duomenis ị natūrinius ir parenkant upių vagų reguliavimo būdus bei priemones.

Raktažodžiai: vaginiai procesai, turbulentinès tèkmès, hidraulinis modeliavimas, masteliai.

\section{МОДЕЛИРОВАНИЕ РУСЛОВЫХ ПРОЦЕССОВ В РЕГУЛИРУЕМЫХ РУСЛАХ РЕК}

\section{С. Вайкасас, М. Станкявичюс}

Резюме

Моделирование русловых процессов и движение влекомых наносов в регулируемых руслах рек тесно связано с моделированием турбулентных флуктуаций прототипа. Это характерно и для моделирования выпуска, а также рассеивания и смешения сточных вод в руслах. Однако моделирование турбулентных флуктуаций руслового потока является сложным и недостаточно исследованным явлением.

В связи с моделированием макромасштабных флуктуаций потока и введением масштабов $\alpha_{\mathrm{Ka}} ; \alpha_{x}$ и $\alpha_{K}$ представлено несколько способов возможного пересчета гидравлических характеристик турбулентного течения. Подчеркивается, что необходимо обращать усиленное внимание на турбулентную структуру потоков при верификации и калибровке физических гидравлических моделей, а также при пересчете данных, полученных путем моделирования. На примерах исследования кинематики рек Нерис и Нямунас в статье представлены примеры упомянутых пересчетов. Показано, что при наличии 12-кратного искажения геометрических масштабов русла реки Нямунас из-за увеличения интенсивности турбулентной флуктуации на модели процесс смешения сточных вод увеличился в 3 раза. Также установлено, что при моделировании руслового процесса реки Нерис в городе Вильнюсе на русловой гидравлической модели с 6- и 7-кратном искажением геометрических масштабов из-за увеличения турбулентности толщина удельного придонного слоя уменьшается на $25 \%$, а вертикальная скорость подъема крупномасштабных водоворотов возрастает почти в 3 раза. Эти обстоятельства принимались во внимание при пересчете модельных данных, а также при подборе способов регулирования русел, средств регулирования и конструкции водовыпускных сооружений.

Ключевые слова: русловые процессы, турбулентные течения, гидравлическое моделирование, масштабные соотношения. 